\title{
THE ANNUAL TESTICULAR CYCLE AND ANDROGEN PRODUCTION IN VITRO IN THE MASKED CIVET CAT, PAGUMA L. LARVATA
}

\author{
H. W. TSUI, * W. H. TAM, $\dagger$ B. LOFTS and J. G. PHILliPS $\ddagger$ \\ Department of Zoology, University of Hong Kong
}

(Received 2nd February 1973)

\begin{abstract}
Summary. The seasonal changes in the capacity of the testicular tissue of the masked civet cat, Paguma l. larvata, to produce testosterone from radioactively labelled pregnenolone in vitro, has been measured chromatographically, together with an analysis of the spermatogenic cycle and the lipid cycle of the interstitial Leydig cells.

Testosterone is the main androgen produced by the civet cat testis in vitro and its production, assessed as a percentage conversion from the precursor added, closely follows the interstitial lipid cycle and seasonal spermatogenic cycle, reaching a peak in March and rapidly declining at the end of the reproductive season. The most active period of testosterone production takes place at a time when the interstitial cells are becoming rapidly depleted of their lipids, and the very rapid decline which takes place in July is marked histochemically by the interstitial tissue entering a heavily lipoidal end-phase.

The possible relationship between the seasonal histochemical events and the rate of androgen synthesis is discussed.
\end{abstract}

\section{INTRODUGTION}

Investigations on the cyclical changes in the functional activity of the vertebrate testis have now been carried out in all the major classes (see reviews by Dodd, 1960; Forbes, 1961; Lofts, 1968; Lofts \& Bern, 1972). By contrast, literature on the seasonal endocrinological fluctuations, particularly in wild mammals, is sparse and has generally been confined to an analysis of the cyclic changes in the germinal epithelium, sexual behaviour, and the development of the secondary and accessory sexual structures. Histochemical data on the testicular components of seasonally breeding mammals are generally lacking, but there is now a considerable literature about such cycles in the non-mammalian vertebrates (see review by Lofts \& Bern, 1972).

In many seasonally breeding non-mammalian vertebrates, the interstitial

* Present address: Department of Zoology, University of California, Berkeley, U.S.A.

† Present address: Department of Zoology, University of Western Ontario, London 72, Ontario, Canada.

† Present address: Department of Zoology, University of Hull, England. 
cells have been found to undergo well-marked cyclic histochemical changes involving a seasonal accumulation and depletion of cholesterol-positive (Schultz test) lipids in the cell cytoplasm, which closely correlates with the pattern of androgen synthesis as indicated by incubations of the tissue with labelled steroid precursors in vitro (Lofts, 1968, 1969; Tam, Phillips \& Lofts, 1969; Lofts \& Bern, 1972). In mammals, however, such parallel studies on histochemical cycles and incubation investigations of the steroidogenic capacity in vitro have not, so far, been undertaken, though a seasonal fluctuation in the testicular androgen content has been shown biochemically in the roebuck, Capreolus capreolus (Short \& Mann, 1966), and red deer stag, Cerous elaphus (Lincoln, 197I). No histochemical data on the endocrinological tissue was recorded in either of these studies. The observations of Lofts (1960) on the annual cycle of the mole, Talpa europaea, suggests that the testes of seasonal mammals also display cyclic lipid changes similar to the recorded events in the lower vertebrate groups. In the mole, there is a gradual accumulation of cholesterol and lipid in the Leydig (interstitial) cells during the months immediately preceding the breeding season, and this is followed by a sharp rise in sudanophilia after shedding of the spermatozoa. This densely lipoidal and cholesterol-rich state lasts for a few weeks, then the lipids gradually become depleted until, by July, the Leydig cells are completely lipid- and cholesterolfree.

It has been suggested that the cholesterol-rich lipoidal material which seasonally appears in the Leydig cells of lower vertebrates, and also Talpa, may be precursor material for the synthesis of androgens, and that the seasonal waxing and waning of this material is an indication of the functional activity of the cell (Lofts, 1968; Lofts \& Bern, 1972). There is, however, a great paucity of information on such cycles in seasonal mammals, and it is with this in mind that an investigation on the seasonal biosynthetic capacity for androgen production in the masked civet cat has been carried out in conjunction with a detailed investigation of the histochemical changes in the testicular tissue. It was felt that such a collateral approach would lead to a better understanding of the functional significance of any histochemical changes that might be revealed in the material.

\section{MATERIALS AND METHODS}

The masked civet cat has a very wide distribution in South China, and also occurs throughout the Malay Peninsula to Sumatra and Borneo. The animals used in the present investigation were trapped in South China and purchased from a dealer in Hong Kong. Adult civets were obtained monthly throughout a complete year and, after killing, the testes were dissected out to provide tissue $(250 \mathrm{mg}$ ) for incubation. The remaining testicular material was used for histological and histochemical examination.

\section{Histology}

The material removed for histological examination was divided and a portion fixed in Bouin's fluid for subsequent embedding in wax, and another in 
formol-saline solution (Baker, 1949) for post-chroming and embedding in gelatine. The wax-embedded material was sectioned at $4 \mu \mathrm{m}$ and stained with iron haematoxylin and orange $G$ for routine analysis of the spermatogenic condition. All measurements of nuclear diameters and diameters of seminiferous tubules, were carried out on this material. The mean of twenty such measurements on randomly selected nuclei was taken as the average for any given specimen. The gelatine-embedded material was sectioned at $4 \mu \mathrm{m}$ on a freezing microtome and stained with Sudan Black B for the demonstration of lipoidal inclusions; carmalum was used as a counterstain. Thicker, $12 \mu \mathrm{m}$, gelatineembedded sections were also cut and used for the Schultz test for cholesterol and unsaturated sterols. The test reacts positively to the presence of a double bond in position 5 or 7 or both, and does not distinguish between free and esterified forms of these various steroids.

\section{Biochemistry}

The testicular tissue was thinly sliced and was always preincubated for 30 min before being transferred to flasks containing the added precursor $(0.318$ $\mu \mathrm{Ci} \Delta^{5}$-pregnenolone-7 $\alpha$-T, Radiochemical Centre, Amersham) together with a

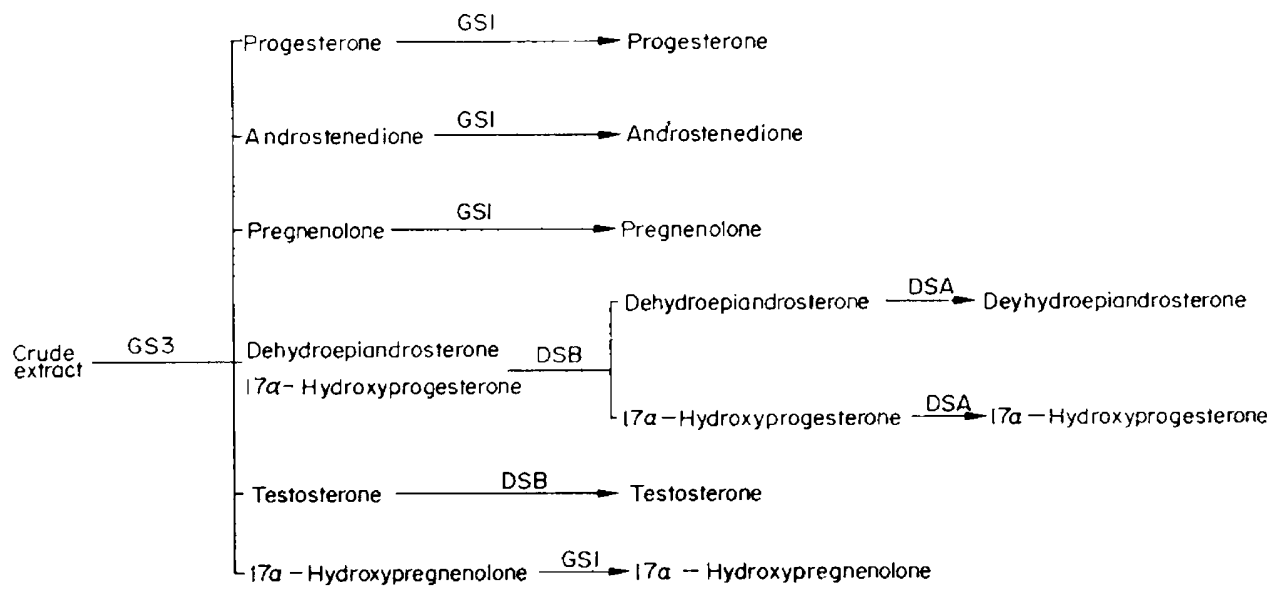

TExT-FIG. 1. Flow sheet for the scheme of steroid separation by thin-layer chromatography.

GSI = light petroleum: benzene: ethyl acetate $(1: 1: 4) ; G S 3=$ toluene: methanol

$(92: 8) ;$ DSA $=$ diethyl ether: chloroform $(1: 9) ; \mathrm{DSB}=$ benzene: ethyl acetate $(1: 1)$.

fresh volume $(10 \mathrm{ml})$ of Krebs-Henselheit Ringer ( $\mathrm{pH} \mathrm{7.4).} \mathrm{The} \mathrm{incubation}$ was carried out for $4 \mathrm{hr}$ at $37^{\circ} \mathrm{C}$ in an atmosphere of $95 \% \mathrm{O}_{2}$ and $5 \% \mathrm{CO}_{2}$. Before extraction, $50 \mu \mathrm{g}$ of the following steroids were added to the incubate as carriers: pregnenolone, 17 $\alpha$-hydroxypregnenolone, progesterone, $17 \alpha$ hydroxyprogesterone, testosterone, androstenedione and dehydroepiandrosterone.

The assay procedure was basically similar to the one described previously by Gottfried, Huang, Lofts, Phillips \& Tam (1967) and Tam, Phillips \& Lofts (1969) for the extraction of testosterone and other neutral and phenolic steroids from testicular incubates. Each monthly incubate was extracted five times with chloroform-ethyl acetate $(1: 1)$, then the pooled organic phase was 
evaporated to dryness in vacuo in a rotary film evaporator. The residue was dissolved in $20 \mathrm{ml}$ petroleum ether and partitioned five times with $70 \%$ aqueous methanol. After the pooled methanolic extracts were evaporated nearly to dryness, the concentrate was made up to $20 \mathrm{ml}$ with distilled water and extracted five times with chloroform. This chloroform fraction was evaporated to dryness under a stream of nitrogen and chromatographed on chromatoplates coated with silica-gel to a thickness of $0.2 \mathrm{~mm}$. The plates were air-dried for $1 \mathrm{hr}$ and activated at $110^{\circ} \mathrm{C}$ for $1 \frac{1}{2} \mathrm{hr}$ before use. The solvent systems used for the separation of the various steroids are summarized in Textfig. 1.

The purified steroids were dissolved in $10 \mathrm{ml}$ of scintillation mixture containing $4 \mathrm{~g}$ of 2,5-diphenyloxazol and $0.1 \mathrm{~g}$ of 1,4-bis-2 (5-phenyloxazolyl)benzene in 1 litre of G.R. grade toluene. Radioactivity was estimated by using a Liquid Scintillation Spectrometer (Model 3303, Packard) and the percentage conversion from the precursor was calculated.

After separation by thin-layer chromatography, $\left[4-{ }^{14} \mathrm{C}\right]$ testosterone was added to the synthesized tritiated testosterone, and the final purification and identification of this steroid was performed by recrystallization to a constant ${ }^{3} \mathrm{H} /{ }^{14} \mathrm{C}$ ratio using acetone/n-pentane as a solvent pair (Axelrod, Matthijssen, Goldzieher \& Pulliam, 1965). The final proof of identification of the isolated steroid required that the specific activity of three consecutive crystallizations were within $\pm 5 \%$ of the mean (Axelrod, 1965; Axelrod et al., 1965; Acevedo \& Goldzieher, 1965; Sharma, Dorfman \& Southren, 1965). None of the other steroids tentatively identified by their mobility in the solvent systems were subjected to recrystallization.

\section{RESULTS}

A male civet was obtained in every month, with the exception of June and September. They were all adults, weighing between 3.4 and $4 \mathrm{~kg}$. The combined testicular weights of each specimen are recorded in Text-fig. 2 and indicate the general pattern of the seasonal cycle; the maximum testicular development coincided with the spring months and declined in the autumn.

\section{Histological changes}

The changes in the diameter of the seminiferous tubules, also outlined in Text-fig. 2, besides reflecting the seasonal build-up of their germinal content, closely parallel the fluctuations in endocrine activity of the whole gonad. The seasonal variations in histological and lipoidal conditions can be classified into four well-defined phases as follows.

Phase I. February to April. This is the pre-nuptial period of spermatogenic recrudescence. In mid-February, seminiferous tubules averaged $108 \mu \mathrm{m}$ in diameter and were lined by a germinal epithelium consisting of a peripheral ring of spermatogonia showing a few mitotic figures and Sertoli cells which tended to block the tubule lumen. Type-A spermatogonia predominated, but a few type-B cells with darkly staining flakes of chromatin arranged on the inner surface of the nuclear membrane (Bloom \& Fawcett, 1962) had begun to 
appear, together with a few isolated primary spermatocytes. The vesiculate interstitial cell nuclei measured $7.5 \mu \mathrm{m}$ in diameter and contained a conspicuous nucleolus. In the frozen-sectioned material, a few small sudanophilic droplets could be seen in the cytoplasm of a few of these cells. Others were lipid free. The tubules were all lipid free.

By March, the tubules had expanded to a mean diameter of $248 \mu \mathrm{m}$ and a clearly defined lumen appeared. Spermatogonial divisions were more numerous and primary spermatocytes also increased in number. A few early cap-phase spermatids could be found in isolated tubules. The interstitial cells were more sudanophilic with numerous small lipoidal droplets (Pl. 1, Fig. 1) which gave a positive Schultz reaction; the nuclear size had increased to $8 \mu \mathrm{m}$.

By the end of April, all spermatogenic stages were represented in the germinal epithelium, but spermatogonial divisions had become less frequent, and fewer

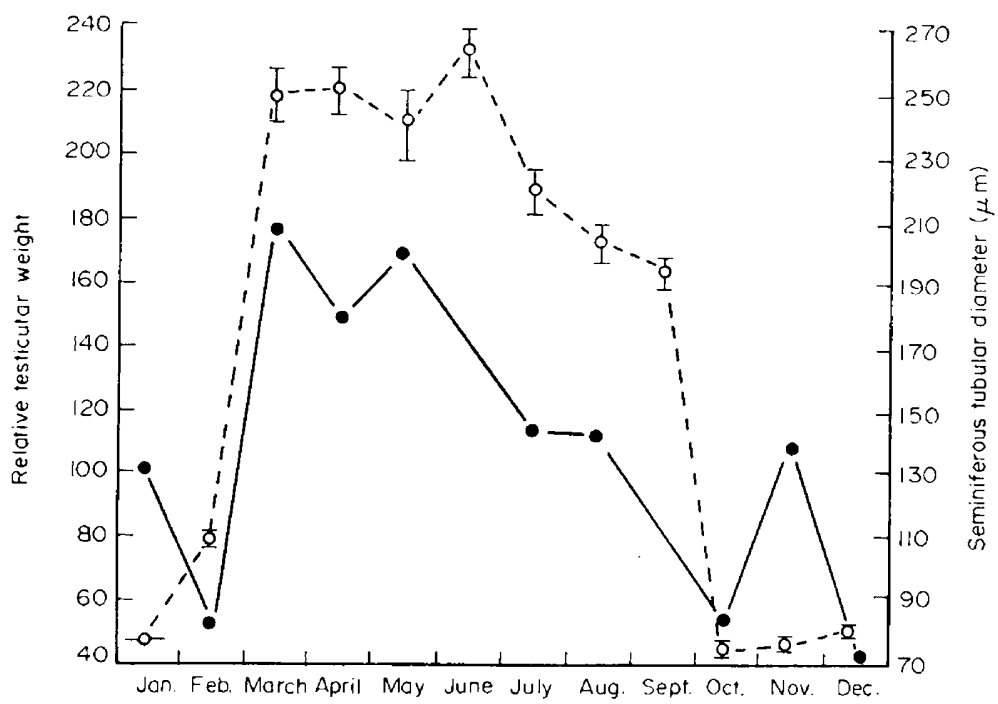

Text-Fig. 2. Seasonal fluctuations in the relative testicular weight and seminiferous tubule diameter in Paguma l. larvata. Testicular weight $(\bullet)$ is expressed as $\mathrm{mg} / 100 \mathrm{~g}$ body weight. Seminiferous tubule diameters $(0)$ are means of twenty randomly selected tubules with the S.E. expressed by the vertical bars.

B-type spermatogonia could be seen. Spermatids were numerous and a few free spermatozoa were present in most tubules. Small sudanophilic residual bodies (Regaud, 1901) could be found in the region of the embedded sperm head, and there was an accumulation of large lipid droplets in the basal region of the tubules, a common feature in the gonads of sexually active mammals (Smith \& Lacy, 1959). The interstitial cells had become almost depleted of their lipid content, and only minute amounts of sudanophilic droplets occurred in their cell cytoplasm which was filled with small refractile granules (Pl. 1, Fig. 2). Only a faint or negative Schultz reaction was given by this tissue. The interstitial cell nuclear diameter had increased to its maximum of $8.47 \mu \mathrm{m}$, suggesting that the tissue was probably active.

Phase II. May to June. The breeding season generally extended from May to 
June, and during this period the seminiferous tubules were greatly expanded (262 $\mu \mathrm{m}$ diameter) with abundant free spermatozoa in the tubule lumina. In the germinal epithelium, the population of spermatogonia and spermatocytes undergoing division had declined from that observed during the previous month, but spermatids were more numerous and spermateleosis and spermiation had reached a peak.

The interstitial tissue in specimens caught during the earlier part of the breeding period showed little change from that recorded in April, but towards the end of this phase in late June, the nuclear size decreased, and the cell cytoplasm became heavily impregnated with large lipid globules giving a strong cholesterol reaction.

Phase III. Fuly to October. This was the post-nuptial period of testicular regression and, histologically, there was an overlap between the condition of specimens examined during the earlier part of this phase and the end of Phase II. Generally, active spermiation had ceased by July and the seminiferous tubules regressed rapidly (Text-fig. 2) to a diameter of only $72 \mu \mathrm{m}$ by October. The tubule lumina had become filled with cellular débris of degenerating germ cells which had sloughed off from the germinal epithelium, and pycnotic nuclei were common. Lipid droplets could be found within the tubules, but, as in the mole, Talpa europaea (Lofts, 1960), and vole, Microtus agrestis (Clarke \& Forsyth, 1963), the massive accumulation of dense sudanophilic material which occludes the 'spent' tubules of lower vertebrates (Lofts, 1968; Lofts \& Bern, 1972) did not occur.

The interstitial cells become densely lipoidal towards the end of the breeding season (Pl. 1, Fig. 3) but, by late July, much of this sudanophilic material had disappeared so that, by August, the interstitium was almost completely free of lipid. There were no refractile granules in the interstitial cell cytoplasm, and the tissue with its smaller cells and shrunken nuclei of only $6.29 \mu \mathrm{m}$ diameter generally gave the impression of a low level of secretory activity. The Schultz reaction failed to demonstrate any unsaturated sterols in this tissue at this stage of the annual cycle.

\section{EXPLANATION OF PLATE 1}

Seasonal changes in the testicular tissue of Paguma l. larvata. Tissue was embedded in gelatine and frozen sections were cut at $4 \mu \mathrm{m}$. Stained with Sudan black and carmalum.

Fig. 1. Testis in March. The seminiferous tubules have started their seasonal recrudescence of spermatogenic activity. The interstitial Leydig cells contain numerous small lipoidal droplets. $\times 160$.

Fig. 2. Testis in April. The seminiferous tubules are at the peak of spermatogenic activity and contain spermatozoa. A scattering of small lipoidal droplets in the tubule lumen marks the position of the residual bodies in the region of the sperm heads. The interstitial Leydig cells, with large rounded nuclei, are depleted of their lipoidal droplets. $\times 225$.

Frg. 3. Testis in late June. The breeding season is over and large lipid globules have appeared in the collapsing seminiferous tubules. The interstitial cells have become densely lipoidal and in many the cell cytoplasm is filled with a dense amorphous mass of sudanophilic material. $\times 160$.

FIg. 4. Testis in December. Both interstitial tissue and seminiferous tubules are lipid free. Within the tubules, 'winter spermatogonia' with their nuclei surrounded by clear cytoplasm are very common. $\times 160$. 
PLATE 1

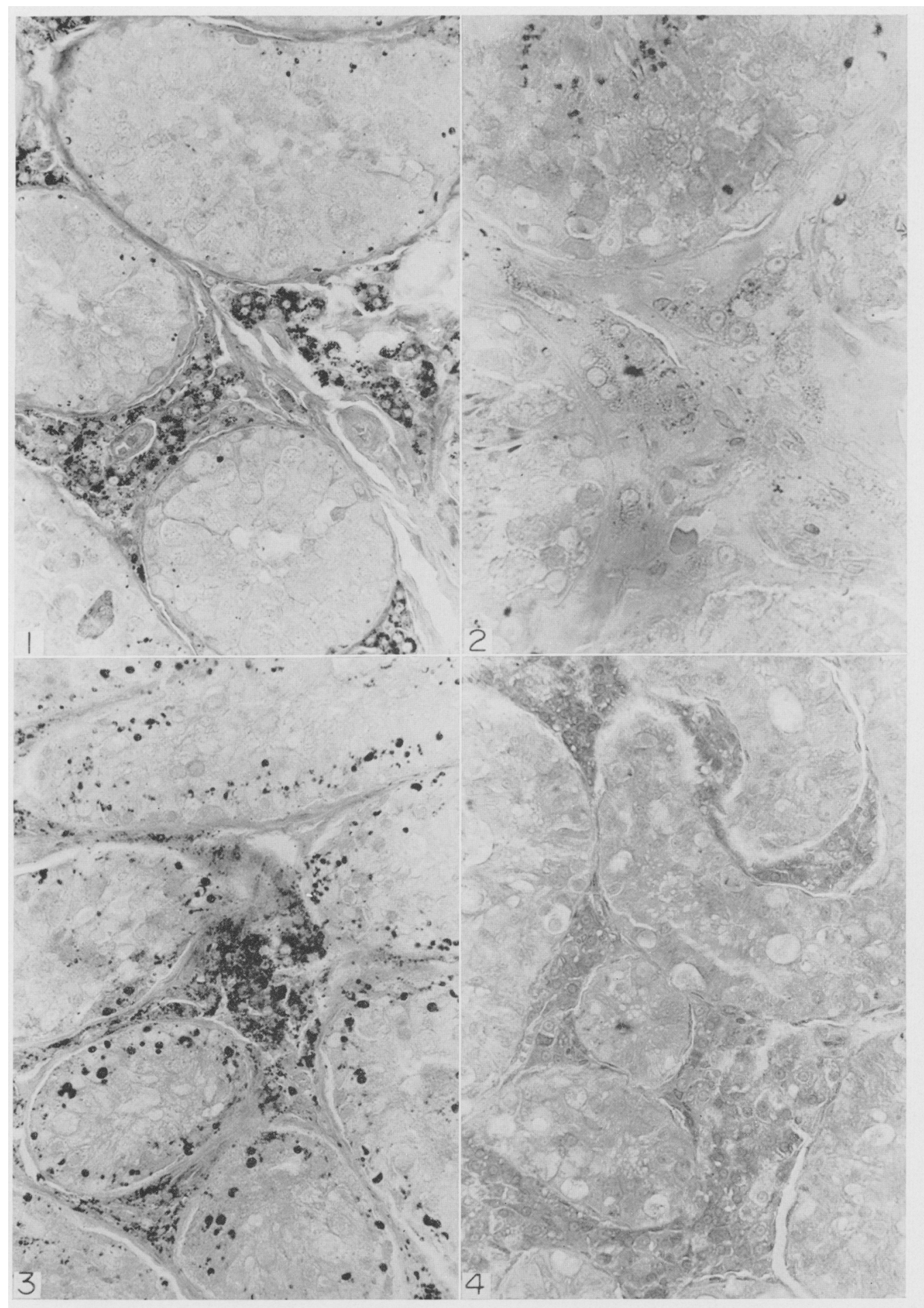

(Facing p. 288) 


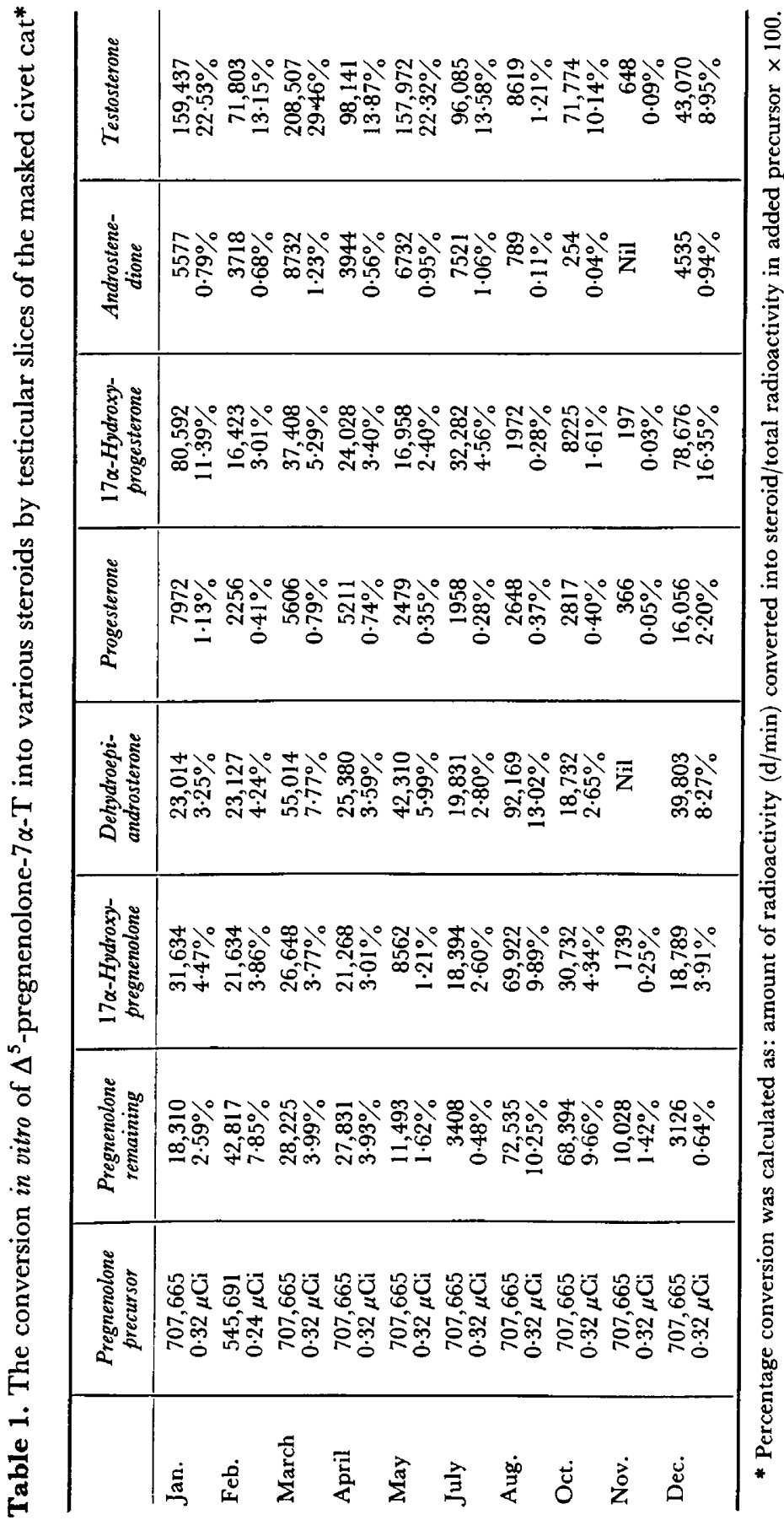


Phase IV. November to January. By November, the cellular débris in the tubule lumina had disappeared, and the lumen was again occluded by hypertrophied Sertoli cells. The germinal epithelium consisted of a peripheral ring of spermatogonia, some of which were enlarged and surrounded by clear cytoplasm, particularly in December and January. Such cells have been described as 'spermatogonies d'hiver' by Courrier (1923). Both intratubular and interstitial cell lipids were absent (Pl. 1, Fig. 4), and a negative cholesterol reaction was obtained.

\section{Steroid biosynthesis}

The seasonal fluctuations in the production of the various steroids are shown in Table 1. Though only the major product, testosterone, was characterized in this study, the other metabolites, which were tentatively identified by their mobility in the thin-layer chromatography systems used, were also included.

Table 2. The synthesis of testosterone by the masked civet cat testis at different times of the year after correction for losses incurred during recrystallization

\begin{tabular}{|c|c|c|c|}
\hline Jan. & $\begin{array}{c}131,682 \mathrm{~d} / \mathrm{min} \\
19.33 \%\end{array}$ & July & $\begin{array}{c}84,031 \mathrm{~d} / \mathrm{min} \\
11.87 \%\end{array}$ \\
\hline Feb. & $\begin{array}{c}54,434 \mathrm{~d} / \mathrm{min} \\
9.98 \%\end{array}$ & Aug. & $\begin{array}{l}5,399 \mathrm{~d} / \mathrm{min} \\
0.76 \%\end{array}$ \\
\hline March & $\begin{array}{c}183,329 \mathrm{~d} / \mathrm{min} \\
25.91 \%\end{array}$ & Oct. & $\begin{array}{c}46,989 \mathrm{~d} / \mathrm{min} \\
6.64 \%\end{array}$ \\
\hline April & $\begin{array}{c}80,395 \mathrm{~d} / \mathrm{min} \\
11 \cdot 36 \%\end{array}$ & Nov. & Background \\
\hline May & $\begin{array}{c}131,566 \mathrm{~d} / \mathrm{min} \\
18.59 \%\end{array}$ & Dec. & $\begin{array}{c}25,631 \mathrm{~d} / \mathrm{min} \\
5.33 \%\end{array}$ \\
\hline
\end{tabular}

The results of recrystallizing the testosterone to constant ${ }^{3} \mathrm{H} /{ }^{14} \mathrm{C}$ ratios, and allowing for losses during recrystallization, are given in Table 2. From this table, it can be seen that the percentage conversions to testosterone show considerable seasonal fluctuations and closely follow the histological phases outlined earlier. Thus, testosterone synthesis was high in testicular material obtained during Phases I and II of the annual cycle, but declined very rapidly towards the end of the breeding season at a time when Leydig cells became densely lipoidal and shrunken, and when the adjacent seminiferous tubules were undergoing their regressive changes (Phase III). Generally, then, androgen production increased rapidly in the spring during the period of recrudescence of spermatogenic activity and did not show a dramatic reduction until the animals underwent a period of spermatogenic inactivity.

\section{DISCUSSION}

It is appreciated that with the limited amount of material that was available, the most that can be deduced from the data are general trends. Nevertheless, a close correlation was observed between the pattern of the seasonal lipid cycle, 
nuclear size, and other histological changes in the interstitial Leydig cells and the biosynthetic capacity of the testicular tissue to produce testosterone from labelled pregnenolone. It seems likely, therefore, that such parameters can be useful indicators of the functional activity of the tissue as far as endogenous androgen production is concerned. Thus, the results tend to support the evidence obtained from similar investigations in other vertebrate groups (Lofts, 1968; Lofts \& Bern, 1972), particularly in reptiles (Tam et al., 1969; Lofts, 1969). When the seasonal fluctuations in testosterone production are compared with the data for Leydig cell nuclear diameter, the close association between these two factors is clearly seen. Increase in testosterone synthesis in vitro is almost always accompanied by an increase in Leydig cell nuclear size, and vice versa.

Lofts (1968) has suggested that since cholesterol is an androgen precursor, the depletion of the Schultz-positive lipoidal material from the Leydig cells at the height of the breeding season is indicative of a rapid utilization at a time of high androgen production, whereas the rapid metamorphosis into a densely lipoidal cell at the end of the breeding season is indicative of a sudden decline in androgen synthesis with a consequent accumulation of precursor material due to its slower utilization. Some of the more recent evidence on the $\Delta^{5}-3 \beta$-hydroxysteroid dehydrogenase activity in this tissue also supports this interpretation. Thus, a strongly positive result is associated with interstitial cells becoming rapidly depleted of their lipoidal content, whereas the heavily sudanophilic post-nuptial interstitium is negative to such tests (Lofts \& Bern, 1972). The peak of androgen synthesis in March and the very sharp reduction at the end of the breeding season which occur in the civet cat also support such an hypothesis.

The overall annual pattern, indicating a marked enhancement of testosterone production in Phases I and II with a subsequent post-nuptial decline to a lower winter level, would probably be even more marked if it were possible to incubate only interstitial tissue. With the seasonal build-up in germinal cell propagation and the consequent enormous expansion in tubule diameters (Text-fig. 2), the interstitial tissue between the expanding tubule elements becomes compressed and dispersed spatially throughout the greatly enlarged gonads, so that quantitatively there will be fewer Leydig cells in the 250-mg slice of tissue dissected from a civet cat in Phase II, than there will be in the same quantity of testicular tissue obtained from the regressed gonads of a civet cat in Phases III or IV. Thus, the higher conversion rates in the spring have been achieved with fewer, but highly active, steroidogenic elements.

When the annual pattern of androgen biosynthesis of the civet cat is compared with that found in the cobra, Naja naja (Tam et al., 1969), a basic difference becomes apparent. In the latter, there is a high titre of androgen in autumn (September to November) and a second, but lesser, peak in spring (February to May), whereas the present results show the main peak to be in spring. Tam et al. (1969) and Lofts (1969) have drawn attention to the close parallel which exists between the seasonal fluctuations in androgen production in this snake and the annual spermatogenic cycle. The cobra, as is common with most poikilothermic vertebrates, shows an intense post-nuptial recrudescence of spermatogenesis in the autumn which coincides with this high androgen production but, in 
homoiothermic vertebrates such as the civet cat, spermatogenic activity generally ceases at the end of the breeding season and the 'spent' seminiferous tubules remain sexually regressed throughout the autumn and winter months. Spermatogenic activity does not resume until the following spring but, as in the reptilian testis, this coincides with the period of high androgen production. It may be that the different spermatogenic cycles which occur in these two different vertebrate groups can be correlated with the differences in the steroidogenic patterns. There is ample evidence of a spermatokinetic effect as a result of exogenous androgen administration in mammals (Albert, 1961; Boccabella, 1963; Harvey, 1963; Clermont \& Harvey, 1967), and high endogenous production might also stimulate the germinal epithelium. In the rat, testosterone appears to be of primary importance in controlling the initial stages of spermatogenesis (Steinberger \& Duckett, 1965, 1967; Lostroh, 1969). In their study of endogenous testosterone concentrations in the roebuck, Short \& Mann (1966) found that the elevation and decline of testosterone closely followed the seasonal spermatogenic cycle, and Lincoln (1971) has also drawn attention to the very close correlation which exists between the seasonal fluctuations in spermatogenesis and endogenous testicular testosterone levels in the red deer stag. Although there appears to be a close link between androgenesis and spermatogenesis in the few seasonal mammals so far studied, it is perhaps premature to conclude that this is a direct influence of the interstitial cells on the germinal epithelium, since there is some evidence that the tubule Sertoli cells may also be loci of androgen synthesis both in mammalian and non-mammalian species (see reviews by Lacy and his co-authors, 1969; Lofts, 1972; Lofts \& Bern, 1972). These cells may have a direct local effect on the gametogenic activity of the germinal epithelium (Lacy \& Lofts, 1965).

\section{REFERENCES}

Acevedo, H. F. \& Goldziener, J. W. (1965) Further studies on the metabolism of 4-[4- $\left.{ }^{14} \mathrm{C}\right]$ androstene-3,17-dione by normal and pathological human prostatic tissue. Biochim. biophys. Acta, 97, 564 .

Albert, A. (1961) The mammalian testis. In: Sex and Internal Secretions, Vol. I, p. 305. Ed. W. C. Young. Williams \& Wilkins, Baltimore.

Axelrod, L. R. (1965) Metabolic patterns of steroid biosynthesis in young and aged human testes. Biochim. biophys. Acta, 97, 551 .

Axelrod, L. R., Matthijssen, G., Goldziener, J. W. \& Pulliam, J. E. (1965) Definitive identification of micro-quantities of radioactive steroids by recrystallization to constant specific activity. Acta endocr., Copenh. Suppl. 99, 7.

Baker, J. R. (1949) Further remarks on the Golgi element. Q. Jl microsc. Sci. 90, 293.

Bloom, W. \& Fawcett, D. W. (1962) A textbook of histology. Saunders, Philadelphia.

BocCABELla, A. V. (1963) Reinitiation and restoration of spermatogenesis with testosterone propionate and other hormones after a long-term post-hypophysectomy regression period. Endocrinology, 72, 787.

Clzarke, J. R. \& Forsyth, I. A. (1963) Seasonal changes in gonads and accessory reproductive organs of the vole, Microtus agrestis. Gen. छ compar. Endocr. 4, 233.

Clermont, Y. \& Harvey, C. S. (1967) Effects of hormones on spermatogenesis in the rat. In: Endocrinology of the Testis. Ciba Foundation Colloquia on Endocrinology, 16, p. 173. Eds. G. E. W. Wolstenholme and M. O'Connor. Churchill, London.

Courrier, R. (1923) Cycle annuel de la glande interstitielle du testicule chez cheiroptères. Coexistence du repos séminal et de l'activité génital. C.r. Séanc. Soc. Biol. 88, 1163.

DodD, J. M. (1960) Gonadal and gonadotrophic hormones in lower vertebrates. In: Marshall's Physiology of Reproduction, Vol. 1, part 2, p. 417. Ed. A. S. Parkes. Longmans Green, London. 
Forbes, T. R. (1961) Endocrinology of reproduction in cold-blooded vertebrates. In: Sex and Internal Secretions, Vol. II, p. 1035. Ed. W. C. Young. Williams \& Wilkins, Baltimore.

Gottraied, H., Huang, D. P., Lofts, B., Phillips, J. G. \& Tam, W. H. (1967) In vitro production of steroids by the adrenal and testicular tissues of the cobra (Naja naja). Gen. E compar. Endocr. $8,18$.

HaRvey, S. C. (1963) The effect of testosterone propionate on germ cell number in the male rat. Anat. Rec. 145, 237.

LACY, D. \& LoFTs, B. (1965) Studies on the structure and function of the mammalian testis. I. Cytological and histochemical observations after continuous treatment with oestrogenic hormone and the effects of FSH and LH. Proc. R. Soc., B, 162, 188.

Lacy, D., Vinson, G. P., Collins, P., Bell, J., Fyson, P., Pudney, J. \& Pettitt, A. J. (1969) The Sertoli cell and spermatogenesis in mammals. In: Progress in Endocrinology, p. 1019. Ed. C. Gual. Exerpta Med., Amsterdam.

Lincoln, G. A. (1971) The seasonal reproductive changes in the red deer stag (Cervus elaphus). F. Zool., Lond. 163, 105.

LoFrs, B. (1960) Cyclical changes in the distribution of testis lipids of a seasonal mammal (Talpa europaea). Q. 7 l microsc. Sci., 101, 199.

LofTs, B. (1968) Patterns of testicular activity. In: Perspectives in Endocrinology: Hormones in the Lives of Lower Vertebrates, p. 239. Eds. E. J. W. Barrington and C. B. Jørgensen. Academic Press, New York and London.

Lorrs, B. (1969) Seasonal cycles in reptilian testes. Gen. E compar. Endocr., Suppl. 2, 147.

LofTs, B. (1972) The Sertoli cell. Gen. \& Compar. Endocr., Suppl. 3, 636.

LOFTs, B. \& BERN, H. A. (1972) The functional morphology of steroidogenic tissues. In: Steroids in Nonmammalian Vertebrates, p. 37. Ed. D. R. Idler. Academic Press, New York and London.

Lostroh, A. J. (1969) Regulation by FSH and ICSH (LH) of reproductive function in the immature male rat. Endocrinology, 85, 438.

REgaud, C. (1901) Etudes sur la structure des séminifères et sur la spermatogenèse chez mammifères. Archs Anat. microsc. 4, 101.

Sharma, D. C., Dorfman, R. I. \& Southren, A. L. (1965) Steroid biosynthesis in vitro by feminizing testes. Endocrinology, 76, 966.

SHORT, R. V. \& MANN, T. (1966) The sexual cycle of a seasonally breeding mammal, the roebuck, Capreolus capreolus. F. Reprod. Fert. 12, 337.

Sмтth, B. V. K. \& LACY, D. (1959) Residual bodies of the seminiferous tubules of the rat. Nature, Lond. $184,249$.

Steingerger, E. \& Duckett, G. E. (1965) Effects of estrogen or testosterone in initiation and maintenance of spermatogenesis in the rat. Endocrinology, 76, 1184.

Steinberger, E. \& Duckett, G. E. (1967) Hormonal control of spermatogenesis. F. Reprod. Fert., Suppl. 2, 75.

TAm, W. H., Phillips, J. G. \& Lofts, B. (1969) Seasonal changes in the in vitro production of testicular androgens by the cobra (Naja naja). Gen. \& compar. Endocr. 13,117. 